OPEN ACCESS

Edited by:

Roger Mcintyre,

University of Toronto, Canada

Reviewed by:

Muhammad Omair Husain,

The University of Manchester,

United Kingdom

Leonardo Emberti Gialloreti,

University of Rome Tor Vergata, Italy

*Correspondence:

Heba Bakr Khoshaim

hkhoshaim@psu.edu.sa

Areej Al-Sukayt

asukayt@psu.edu.sa

Specialty section:

This article was submitted to

Mood and Anxiety Disorders,

a section of the journal

Frontiers in Psychiatry

Received: 14 July 2020 Accepted: 12 November 2020 Published: 11 December 2020

Citation:

Khoshaim HB, Al-Sukayt A, Chinna K,

Nurunnabi $M$, Sundarasen $S$,

Kamaludin K, Baloch GM and

Hossain SFA (2020) Anxiety Level of

University Students During COVID-19

in Saudi Arabia.

Front. Psychiatry 11:579750.

doi: $10.3389 /$ fpsyt.2020.579750

\section{Anxiety Level of University Students During COVID-19 in Saudi Arabia}

\author{
Heba Bakr Khoshaim ${ }^{1 *}$, Areej Al-Sukayt ${ }^{2 *}$, Karuthan Chinna ${ }^{3}$, Mohammad Nurunnabi $^{2}$, \\ Sheela Sundarasen ${ }^{2}$, Kamilah Kamaludin ${ }^{2}$, Gul Mohammad Baloch ${ }^{3}$ and \\ Syed Far Abid Hossain ${ }^{4}$
}

${ }^{1}$ Deanship of Educational Services, Prince Sultan University, Riyadh, Saudi Arabia, ${ }^{2}$ Department of Accounting, Prince Sultan University, Riyadh, Saudi Arabia, ${ }^{3}$ Faculty of Health and Medical Sciences, School of Medicine, Taylor's University, Subang Jaya, Malaysia, ${ }^{4}$ College of Business Administration, IUBAT - International University of Business Agriculture and Technology, Dhaka, Bangladesh

COVID-19 is the worst pandemic of this millennium, and it is considered to be the "public enemy number one." This catastrophe has changed the way we live in the blink of an eye. Not only has it threatened our existence and health status, but the damage associated with it could equally affect our economic, social, and educational systems. The focus of this study was on the anxiety level of university students during the COVID-19 pandemic in Saudi Arabia. The study was conducted between March and June 2020. A questionnaire was administered online, and 400 completed questionnaires were returned. In this study, the Zung self-rating anxiety scale was used to determine the anxiety levels among the respondents. The results indicated that about $35 \%$ of the students experienced moderate to extreme levels of anxiety. Anxiety was highly associated with age, sex, and level of education. These findings can enlighten government agencies and policy makers on the importance of making prompt, effective decisions to address students' anxiety during the COVID-19 pandemic. Researchers are encouraged to focus their future studies on how to develop strategies to boost students' resilience and enhance their adaptability skills for similar disasters in the future.

Keywords: pandemic, university students, anxiety, Saudi Arabia, COVID-19, women anxiety

\section{INTRODUCTION}

The COVID-19 disease is the worst pandemic outbreak in the new millennium. Caused by the severe acute respiratory syndrome coronavirus 2 (SARS-CoV-2), the first case was detected in December 2019 in Wuhan, China. Since then, the disease has spread to almost every part of the globe. The spread of the disease was so fast that on January 30, 2020, the WHO declared COVID-19 to be a Public Health Emergency of International Concern. As of April 2020, almost 3 million positive cases were confirmed worldwide, with about 200,000 fatalities (1). In view of the high number of secondary cases arising from one primary case and the population being largely susceptible to infection, the WHO declared COVID-19 disease as a pandemic on March 12, 2020 (2). To control the spread of the disease, China and many other countries imposed lockdowns, either nationwide or in places severely affected by the virus. Educational institutions, financial institutions, centers of economic activities, and amusement centers closed indefinitely $(2,3)$. It is estimated that as of April 2020, more than 300 million students were affected by COVID-19 globally (4). Worldwide, many schools and colleges either closed or resorted to distance learning. Public gathering and celebrations were prohibited. People with severe infection were treated in hospitals, and the less 
severe patients were placed in quarantine centers. These measures are similar to those that have previously proven effective during the H1N1 pandemic as reported by Sakaguchi et al. (5) and during SARS as reported by Ries (6).

In the Kingdom of Saudi Arabia (KSA), the Ministry of Health (MOH) announced the first COVID-19 case on March 2, 2020, and by the end of the month, 154 new COVID-19 cases were reported (7). Anticipating widespread infection, government agencies swiftly implemented several control measures to combat the spread of the virus. In view of mass gatherings, Umrah in Mecca and visitations to the Prophet's Mosque in Madina were suspended immediately, and all the mosques in the country closed temporarily (810). Quarantining of infected people and practicing social distancing became the norm. Universities and schools were closed, switching to virtual classes, to ensure uninterrupted teaching. Students were expected to continue studies from their place of residence. Despite the awareness campaigns and precautionary measures taken by the government, the number of cases continued to increase. Within 3 months, the confirmed cases escalated to 98,869 , out of which 71,791 recovered, and 642 died (11).

In addition to the risk of infection and possible death, an epidemic also exerts tremendous psychological pressure on people worldwide (12-17). Several studies have discussed the short- and long-term effects of epidemics on the social and psychological well-being in the population (18-20). Those who were tested positive for a disease continue to be stigmatized and suffer from seclusion in their own society even after they have recovered $(19,21)$. Those quarantined experienced psychological stressors including "longer quarantine duration, infection fears, frustration, limited supplies, insufficient communication, financial loss, and stigma" [21, p. 1]. Brooks et al. (22) expect that COVID-19 will result in drastic post-traumatic stress symptoms, confusion, and anger.

Moreover, anxiety level among college-level students is already a public health concern. In fact, several previous researches have examined students' anxiety, depression, and stress and have discussed factors that might affect students' mental health (23-32). Looking at students in the Kingdom of Saudi Arabia, Amr et al. (27) reported a $20 \%$ level of anxiety among college-level Saudi students, while Al-Gelban (26) argued that $14.3 \%$ of secondary school students experience anxiety. In contrast, Al-Gelban (25) and Al-Gelban et al. (33) reported a much higher anxiety level (48.9 and 66.2\%, respectively) among high school students. Given that the spread of COVID-19 and the switch to virtual learning are unprecedented and unexpected experiences in Saudi Arabia, we can expect such circumstances to be associated with major psychological challenges for the students. The fear of getting infected or losing loved ones to the disease while having to rapidly adjust to the new teaching and assessment procedures would have had a tremendous pressure on the students. At this time, besides testing, planning, and implementing new teaching and learning environments, educational institutions need to assess the students' psychological well-being so that appropriate measures can be taken to help students cope with unprecedented changes. The purpose of this study is to assess the anxiety status of students in Saudi Arabia during COVID-19 pandemic.

\section{RESEARCH METHODOLOGY}

\section{Participants, Procedures, and Timeline of Survey}

This study examined the anxiety level among university students in Saudi Arabia, specifically in Riyadh, at the time of the COVID19 pandemic. Riyadh is the capital of Saudi Arabia and one of the largest cities in the Kingdom, with an area of $1,798 \mathrm{~km}^{2}$ and a population estimated at 7,231,447 (34). The sample was chosen from one private university. The total number of undergraduate students of both genders currently enrolled in this university is 5,057 students, comprising 3,085 female and 1,972 male students. An online questionnaire created in Google Forms was distributed via email to all undergraduate students at this university. Data were collected from April 20, 2020, to June 6, 2020. Although this period is not ideal as it is at the end of the academic year, the authors preferred to address this concern while the COVID19 concern is at its maximum instead of waiting until the end of summer. The students were briefed on the purpose, and anonymity and confidentiality of their responses. Permission to conduct this study was obtained from the Institutional Review Board (IRB) of the university.

\section{Research Instrument}

In this study, the anxiety level was assessed using Zung's selfrating anxiety questionnaire, a validated 20-item self-report instrument (35) with reported Cronbach's alpha $=0.897$ and internal correlation $=0.913$ (36). The instrument employs a four-point Likert scale where: " $1=$ Never or very rare," "2 = Sometimes," " 3 = Often," and " $4=$ Very Often or always." Questions 1-5 characterize the emotional pointers of anxiety, whereas questions 6-20 signify the physical symptoms of anxiety. For each respondent, the sum of the scores for 20 items ranges from 20 to 80 . The sum of scores are then converted to an "Anxiety Index" with values ranging from 25 to 100 Following the recommendations from Zung (37) and Dunstan and Scott (38), an Anxiety Index $<45$ indicates "Anxiety within normal range," a value in the range of 45-59 indicates "Mild to moderate anxiety," a value in the range of 60-74 indicates "Marked to severe anxiety", and values $\geq 75$ indicates "Most extreme anxiety." Apart from Zung's self-rating anxiety scale, demographic information such as age, gender, year of study, field of study, and living arrangements during the pandemic were also recorded. Moreover, the participants had the chance to reflect on their feelings through open-ended sections. Although Arabic is the mother tongue of the Saudi population, English is the language of instruction at this university. Hence, the instrument was used in its original language and was not translated.

\section{Data Analysis}

The IBM SPSS version 22 software (39) was used in data analysis. Chi-square and ordinal regression procedures were used to determine the factors associated with levels of anxiety. All the 
TABLE 1 | Demographic characteristics of the respondents.

\begin{tabular}{lcc}
\hline Variable & Frequency & Percentage \\
\hline Gender & & \\
Female & 301 & $75.2 \%$ \\
Male & 99 & $24.8 \%$ \\
Age & & \\
S18 years & 15 & $3.8 \%$ \\
19-25 years & 374 & $93.5 \%$ \\
$\geq 26$ & 11 & $2.8 \%$ \\
College & & \\
Business Administration & 131 & $32.8 \%$ \\
Computing and IS & 73 & $18.2 \%$ \\
Engineering & 65 & $16.2 \%$ \\
Humanities & 16 & $4.0 \%$ \\
Law & 69 & $17.2 \%$ \\
Preparatory year program & 46 & $11.5 \%$ \\
Level of study & & \\
Preparatory year program & 79 & $19.8 \%$ \\
Undergraduate & 321 & $80.2 \%$ \\
Year of study & & \\
Year 1 & 127 & $31.8 \%$ \\
Year 2 & 72 & $18.0 \%$ \\
Year 3 & 74 & $18.5 \%$ \\
Year 4 & 72 & $18.0 \%$ \\
Year 5 and above & $55.8 \%$ \\
Current accommodation & & \\
Family home & & $5.8 \%$ \\
Rented premises & & \\
Currently staying with & & \\
Family/relatives & & \\
Alone & & \\
\hline & & \\
\hline
\end{tabular}

variables that were significant at 0.25 level (40) in the chi-square tests were tested in ordinal logistic regression analysis.

\section{Ethical Clearance}

Permission to conduct this study was obtained from the Institutional Review Board (IRB) of the university.

\section{RESULTS}

The aim of this study was to examine the anxiety level of university students in Saudi Arabia during the COVID19 pandemic.

\section{Demographic Characteristics}

The questionnaire was sent to 5,057 undergraduate students, which comprise the population of this university at that time. A total of 400 responses were received, which represents an $8 \%$ response rate. Although this is a low response rate, it might be because the questionnaire was sent at the end of the semester and the beginning of final exams. The demographic characteristics of the respondents are shown in Table 1. Out of
TABLE 2 | Anxiety levels based on Zung's classification.

\begin{tabular}{lccccc}
\hline Anxiety & Frequency & Percentage & Anxiety & Frequency & Percentage \\
\hline $\begin{array}{l}\text { Normal } \\
\text { Minimal to }\end{array}$ & 262 & $65.5 \%$ & Normal & 262 & $65.5 \%$ \\
moderate & 86 & $21.5 \%$ & $\begin{array}{c}\text { Minimal to } \\
\text { moderate }\end{array}$ & 86 & $21.5 \%$ \\
$\begin{array}{l}\text { Marked to } \\
\text { severe }\end{array}$ & 35 & $8.8 \%$ & $\begin{array}{l}\text { Severe to } \\
\text { extreme }\end{array}$ & 52 & $13.0 \%$ \\
Most extreme & 17 & $4.3 \%$ & & & \\
\hline
\end{tabular}

the 400 respondents, $75.25 \%$ (301) were females, and $24.75 \%$ (99) were males and most of the respondents (93.5\%). The skewed response rate toward females could be due to the fact that the females represent around $60 \%$ (3,085 female students) of the population of the university. Most of the respondents (93.5\%) were in the age group of 19-25 years. Regarding their field of study, about one-third of the students were from the College of Business Administration, and around one-sixth each were from the College of Law and the College of Computer and Information Sciences. Most of the students (80\%) were undergraduates, and $20 \%$ were in the Preparatory Year Program (PYP), which is a compulsory 1-year program for all high school graduates. In terms of accommodation, $89.8 \%$ (359) were living at homes owned by their parents, and only around $10 \%$ were living at rented facilities. Moreover, $94.2 \%$ of the students were staying with their families at the time of the pandemic.

\section{Levels of Anxiety}

Among the respondents, $21.5 \%$ (86), $8.8 \%$ (35), and $4.3 \%$ (17) experienced "minimal to moderate," "marked to severe," and "most extreme" levels of anxiety, respectively. For further analysis, respondents in the "marked to severe" and "most extreme" anxiety category were grouped together as "severe to extreme" level of anxiety. A summary of the results is shown in Table 2.

\section{Factors Associated With College Students' Anxiety During the Epidemic} Results From Univariate Analysis

In the univariate analyses, chi-square tests were used to determine the associations between students'demographic variables and anxiety levels. The results are shown in Table 3. Among the demographic variables, gender, age, year of study, and living arrangement were significant at a 0.25 level.

\section{Results From Ordinal Regression Analysis}

The variables of gender, age, year of study, and living arrangement that were significant at the 0.25 level in the univariate analyses were further tested using ordinal logistic regression analysis. In this analysis, only gender and year of study were significant (Table 4). Interestingly, female students were more prone to higher levels of anxiety compared to males (OR = $1.963,95 \% \mathrm{CI}=1.160,3.322, P=0.012$ ). Students in their fourth year were more anxious compared to students in their fifth year or final year $(\mathrm{OR}=2.440,95 \% \mathrm{CI}=1.150,5.179, P=0.020)$. 
TABLE 3 | Results of univariate analyses.

\begin{tabular}{|c|c|c|c|c|c|}
\hline Variable & Normal & $\begin{array}{l}\text { Minimal to } \\
\text { moderate }\end{array}$ & $\begin{array}{l}\text { Severe to } \\
\text { extreme }\end{array}$ & $\begin{array}{l}\text { Chi- } \\
\text { square }\end{array}$ & $p$-value \\
\hline Gender & & & & 7.465 & 0.024 \\
\hline Female & $186(61.8 \%)$ & 71 (23.6\%) & 44 (14.6\%) & & \\
\hline Male & 76 (76.8\%) & 15 (15.2\%) & $8(8.1 \%)$ & & \\
\hline Age & & & & 3.277 & 0.194 \\
\hline$\leq 18$ & $7(46.7 \%)$ & $4(26.7 \%)$ & $4(26.7 \%)$ & & \\
\hline$\geq 19$ & 255 (96.2\%) & $82(21.3 \%)$ & 48 (12.5\%) & & \\
\hline College & & & & 6.862 & 0.738 \\
\hline $\begin{array}{l}\text { Business } \\
\text { administration }\end{array}$ & 90 (68.7\%) & 28 (21.4\%) & 13 (9.9\%) & & \\
\hline Computing and IS & 49 (67.1\%) & 15 (20.5\%) & $2(12.3 \%)$ & & \\
\hline Engineering & 38 (58.5\%) & 17 (26.2\%) & 10 (15.4\%) & & \\
\hline Humanities & $10(62.5 \%)$ & $5(31.2 \%)$ & $1(6.2 \%)$ & & \\
\hline Law & $43(62.3 \%)$ & 15 (21.7\%) & 11 (15.9\%) & & \\
\hline $\begin{array}{l}\text { Preparatory year } \\
\text { program }\end{array}$ & 32 (69.6\%) & $6(13.0 \%)$ & $8(17.4 \%)$ & & \\
\hline Level of study & & & & 0.918 & 0.632 \\
\hline PYP & 55 (69.6\%) & 14 (17.7\%) & 10 (12.7\%) & & \\
\hline Undergraduate & 207 (64.5\%) & 72 (22.4\%) & 42 (13.1\%) & & \\
\hline Year of study & & & & 12.569 & 0.129 \\
\hline Year 1 & $86(67.7 \%)$ & 22 (17.3\%) & 19 (15.0\%) & & \\
\hline Year 2 & $50(69.4 \%)$ & 17 (23.6\%) & $5(6.9 \%)$ & & \\
\hline Year 3 & 48 (64.9\%) & $16(21.6 \%)$ & 10 (13.5\%) & & \\
\hline Year 4 & 37 (51.4\%) & 23 (31.9\%) & $12(16.7 \%)$ & & \\
\hline Year 5 and above & $41(74.5 \%)$ & $6(14.5 \%)$ & 6 (10.9\%) & & \\
\hline Accommodation & & & & 0.630 & 0.730 \\
\hline Family home & 233 (64.9\%) & 79 (22.0\%) & 47 (13.1\%) & & \\
\hline Rented premises & $29(70.7 \%)$ & $7(17.1 \%)$ & $5(12.2 \%)$ & & \\
\hline $\begin{array}{l}\text { Living } \\
\text { arrangement }\end{array}$ & & & & 3.488 & 0.175 \\
\hline Alone & $14(60.9 \%)$ & $8(34.8 \%)$ & $1(4.3 \%)$ & & \\
\hline Family/Relatives & 248 (645.8\%) & 78 (50.7\%) & $51(13.5 \%)$ & & \\
\hline
\end{tabular}

\section{Open-Ended Questions}

In the Google form, the students were asked open-ended questions requiring them to reflect on their feelings and concerns regarding the COVID-19 pandemic. Some of the positive comments from the students were:

"Personally, I got a lot more work done and a lot more sleep than usual."

"It is great and much better than regular classes."

"Everything will be OK."

"I'm using my time wisely during covid-19."

"The freedom of learning from home is very appealing to me."

Regarding the question on concerns, a majority of the concerns reported were financial in nature, such as about their ability to pay for the next semester, the possibility of increased tuition fees, and the loss of income for the provider of their family. Some students wanted the university to decrease the fee for this semester to cope with the challenges. Some of the financial concerns as expressed by the students were:
TABLE 4 | Results from ordinal multivariate analysis.

\begin{tabular}{lcccc}
\hline Parameter & B & SE & p-value & OR $_{\text {adj }}(\mathbf{9 5} \%$ CI) \\
\hline $\begin{array}{l}\text { Gender } \\
\text { Female }\end{array}$ & $\begin{array}{c}0.674 \\
\text { ref }\end{array}$ & 0.269 & 0.012 & $1.963(1.160,3.322)$ \\
$\begin{array}{l}\text { Male } \\
\text { Age }\end{array}$ & & & & 1 \\
$\leq 18$ years & 0.870 & 0.530 & 0.101 & $2.386(0.845,6.739)$ \\
$\geq 19$ years & ref & & & 1 \\
Year of study & & & & \\
Year 1 & 0.155 & 0.3723 & 0.678 & $1.167(0.563,2.422)$ \\
Year 2 & 0.139 & 0.4020 & 0.729 & $1.149(0.523,2.537)$ \\
Year 3 & 0.394 & 0.3927 & 0.316 & $1.483(0.687,3.201)$ \\
Year 4 & 0.892 & 0.3840 & 0.020 & $2.440(1.150,5.179)$ \\
Year 5 and above & ref & & & 1 \\
Living arrangement & & & & 1 \\
Alone & -0.116 & 0.431 & 0.780 & $0.891(0.382,2.074)$ \\
Family/Relatives & ref & & & 1 \\
\hline
\end{tabular}

B, regression coefficient; SE, standard error; OR, odds ratio; Cl, confidence interval.

"My family business got affected by the coronavirus, and I'm
having troubles in this regard."
"I'm afraid that [the college] might increase the fees to the point
where I can't afford to finish my studies."

In addition to financial concerns, the students were also concerned about the uncertainties regarding assessments and how they would be graded.

\section{DISCUSSION}

College students around the world suffer from psychological morbidity, particularly depression and anxiety, due to concerns about the future and academic pressure such as managing stressful tasks and assignments and pursuit to improve their academic performance $(24,29,30,32,41-44)$. A variety of studies have shown that college students in Saudi Arabia share the same symptoms of anxiety and stress and recorded a prevalence of depression and anxiety ranging from 14 to $50 \%$ [e.g., (25-27)]. On the other hand, Inam (45) reported around 66 and $44 \%$ level of anxiety and depression in females and males, respectively, when looking at Saudi medical school students, while Al-Gelban et al. (33) argued that $66 \%$ of the female high school students in Saudi Arabia experienced some level of anxiety. Similarly, a study by Bahhawi et al. (28) showed that students experienced some symptoms of depression (53.6\%) and anxiety (65.7\%) among the samples. In addition, Al Salman et al. (46) examined female secondary school students during the academic year 2018-2019 and reported around $35 \%$ level of moderate anxiety and $10 \%$ of severe anxiety.

The presence of COVID-19 is an additional factor for students to be stressed and anxious about (15). Several studies have addressed psychological well-being during the COVID19 pandemic [e.g., (15, 47-49)] and other past epidemics [e.g., $(6,50-52)]$, either on students [e.g., (47)] or others 
[e.g., (21,53-55)], who postulated that psychological health during pandemics must be addressed. Based on the findings of the current study, around $35 \%$ of the students experienced some level of anxiety, with $13 \%$ having severe to extreme levels. This is consistent with the research done by Alyami et al. (47), which looked at the anxiety level of the Saudi society during COVID-19 and reported 26\% level of anxiety. Moreover, it is more or less similar to what was reported about students in Saudi Arabia before COVID-19 $(25,27,28,33)$. This indicates that the level of anxiety was almost consistent with pre-pandemic status. In fact, Bahhawi et al. (28) reported a higher level of anxiety. Looking outside Saudi Arabia, Cao et al. (48) found that $0.9 \%$ of college students experienced severe anxiety during COVID-19, while around $24 \%$ experienced mild to moderate levels, which presents a low level of anxiety compared to previous literature on college students in general. However, considering that Cao et al. (48) study was conducted on college students in China at the early stage of COVID-19, we can see that the lack of the full picture of this pandemic might have contributed to these results.

The argument that females are more vulnerable than men to disasters is not a new topic (56). The fact that the female students experienced higher levels of anxiety is also not surprising. Previous studies show that college female students report more stress than male students in general $(28,45,57)$. In fact, comparing the two studies by AlGelban (25) and Al-Gelban (26) shows that using the same instrument on male and female students provided different results. While only $59.4 \%$ of the male students had one of three symptoms, $73.4 \%$ of female students had the same. We must keep in mind that the two studies are 2 years apart. Even at the post-graduate level, Almalik et al. (58) argued that female students have a significantly higher anxiety level than male students. Moreover, Huang et al. (59) argue that Chinese females experience more anxiety than males during COVID-19.

One surprising finding was the association between anxiety and the level of study; students in their fourth year were more anxious compared to students in their fifth or final year. However, one might expect that as a student progresses in his or her level of study, any consequences brought about by the pandemic would be nearly permanent and unfixable, and so fifth-year students might be more anxious than fourth-year students. Nevertheless, the fact that fifth-year students had less anxiety than their colleagues in the fourth year is also justifiable. These students were either (1) in their cooperative training program (co-op), so their graduation or academic attainment is not expected to be influenced by the virtual education decision as most of the co-op companies have arranged for an online working/training environment, or (2) in their last semester of courses; in this case, given the implementation of a special grading scheme imposed by the Ministry of Education in Saudi Arabia, a low grade point average for a student would not have an impact, regardless of the final results. Thus, these students were somehow more relaxed, at least with regard to their educational future. This explanation is supported by the reflections from some of the fourth-year respondents, such as:

"My top concern right now is whether we will be returning to the university for the first semester. It is my last semester before coop and all my courses have labs which will be near impossible to achieve in online classes."

"I'm nervous about registering the next semester and might not have the courses that I planned to take to graduate."

\section{CONCLUSIONS, IMPLICATIONS, AND FUTURE RESEARCH}

COVID-19 has been a catastrophic experience; in the blink of an eye, this dreadful pandemic abruptly changed the way we live. As reported in the literature, pandemics are expected to have undesirable consequences not only in terms of health but also on economic, political, and educational systems $(60,61)$. Hence, it is imperative that the world cooperates to fight this pandemic. In that, educational institutions are advised to establish preoutbreak policies and procedures to deal with epidemics (62).

This study is part of a more comprehensive project that aims to address the psychological well-being of university students in several parts of the world during COVID-19. The results of this study give valuable insights into the psychological status of students at a crucial time, and this, of course, has its own merit. However, it is equally crucial that future researches focus on and suggest solutions to address any effects associated with pandemics. It is important to identify appropriate strategies that could help students not only cope with adverse effects of the current pandemics but that can also enhance students' resilience to similar disasters in the future. Parents, educators, and the society as a whole should identify ways to enhance students' adaptability skills that will enable them to cope in such situations.

Moreover, future research may utilize a mixed methodology approach or large-scale comparative studies with collaborations with other countries to look at potential coping strategies that have been proven to be effective in past pandemics or during the current one (63). This might guide policy makers to develop risk management protocols as part of their policy for the future to contain future pandemics (64). Most importantly, as much as we are convinced that COVID19 is the current enemy of humanity, we must be aware of associated impact and be able to respond effectively to all consequences.

\section{LIMITATIONS}

This study aimed to elucidate the anxiety level of Saudi collegelevel students at the time of COVID-19. However, due to time constraints and to avoid a long protocol of obtaining IRB from several universities, this research only focused on one university. Although this is a small-sample study, the results can be enlightening especially since such a pandemic is a novel experience for the Saudi population, and so any data will be 
welcomed. The results can, hence, guide future research on COVID-19 or other epidemics.

\section{DATA AVAILABILITY STATEMENT}

The raw data supporting the conclusions of this article will be made available by the authors, without undue reservation.

\section{ETHICS STATEMENT}

The studies involving human participants were reviewed and approved by Research and Initiative Center at Prince Sultan University. Written informed consent for participation was not required for this study in accordance with the national legislation and the institutional requirements.

\section{REFERENCES}

1. World Health Organization. Coronavirus Disease 2019 (COVID-19), Situation Report-98. World Health Organization (2020). Available online at: https:// www.who.int/docs/default-source/coronaviruse/situationreports/20200427sitrep-98-covid-19.pdf?sfvrsn=90323472_4 (accessed September, 2020).

2. Viner RM, Russell SJ, Croker H, Packer J, Ward J, Stansfield C, et al. School closure and management practices during coronavirus outbreaks including COVID-19: a rapid systematic review. Lancet Child Adol Health. (2020) 4:397-404. doi: 10.1016/S2352-4642(20)30095-X

3. Anderson RM, Heesterbeek H, Klinkenberg D, Hollingsworth TD. How will country-based mitigation measures influence the course of the COVID-19 epidemic? Lancet. (2020) 395:931-4. doi: 10.1016/S0140-6736(20) 30567-5

4. McCarthy K. The Global Impact of Coronavirus on Education. [Video]. ABC News Network (2020). Available online at: https://abcnews.go.com/ International/global-impact- coronavirus- education/story? $\mathrm{id}=69411738$ (accessed August, 2020).

5. Sakaguchi H, Tsunoda M, Wada K, Ohta H, Kawashima M, Yoshino Y, et al. Assessment of border control measures and community containment measures used in Japan during the early stages of pandemic (H1N1) 2009. PLoS ONE. (2012) 7:1-9. doi: 10.1371/journal.pone.0031289

6. Ries NM. Chapter 3: the 2003 SARS outbreak in Canada: Legal and ethical lessons about the use of quarantine. In: Balint J, Philpott $\mathrm{S}$, Baker R, Strosberg M, editors. Ethics and Epidemics Advances in Bioethics. Bingley: Emerald Group Publishing Limited (2006). p. 43-67. doi: 10.1016/S1479-3709(06)09003-0

7. Ministry of Health. MOH Reports 3,121 New COVID-19 Cases, Reiterates the Importance of Social Distancing. (2020). Available online at: https://www. moh.gov.sa/en/Ministry/MediaCenter/News/Pages/News-2020-06-06-001. aspx (accessed July, 2020).

8. Ministry of Foreign Affairs. Saudi Arabia Temporarily Suspends Entry of GCC Member States' Citizens to Makkah, Madinah. (2020). Available online at: https://www.spa.gov.sa/viewfullstory.php?lang=en\&newsid=2040697 (accessed July, 2020).

9. Naar I, Alfaisal L. Saudi Arabia Suspends Umrah for Nationals, Residents over Coronavirus Fears. Al Arabiya English (2020). Available online at: https:// english.alarabiya.net/en/News/gulf/2020/03/04/Saudi-Arabia-stops-UmrahProphet-mosque-visits-to-prevent-coronavirus-spread (accessed June, 2020).

10. Yezli S, Khan A. COVID-19 social distancing in the Kingdom of Saudi Arabia: bold measures in the face of political, economic, social and religious challenges. Travel Med Infect Dis. (2020) 37:101692. doi: 10.1016/j.tmaid.2020.101692

11. Ministry of Health. Kingdom Has Abundant Quantities of Basic Food Commodities, COVID-19 Monitoring Committee Stresses. (2020). Available online at: https://www.moh.gov.sa/en/Ministry/MediaCenter/News/Pages/ News-2020-03-30-006.aspx (accessed June, 2020).

\section{AUTHOR CONTRIBUTIONS}

HK, AA-S, and KK were responsible about data collection process. Data statistics was completed mainly by KC. The introduction, discussion, and conclusion parts were completed by all authors including HK, AA-S, KC, MN, SS, KK, GB, and $\mathrm{SH}$. All authors contributed to the article and approved the submitted version.

\section{FUNDING}

The researchers would like to acknowledge Prince Sultan University for its support for this project through the PSU COVID-19 Emergency Research Program (Grant ID: COVID19-CBA-2020-39).

12. Bai Y, Lin C-C, Lin C-Y, Chen J-Y, Chue C-M, Chou P. Survey of stress reactions among health care workers involved with the SARS outbreak. Psy Serv. (2004) 55:1055-7. doi: 10.1176/appi.ps.55.9.1055

13. Duan Li, Zhu G. Psychological interventions for people affected by the COVID-19 epidemic. Lancet Psy. (2020) 7:300-2. doi: 10.1016/S2215-0366(20)30073-0

14. Jiao WY, Wang LN, Liu J, Fang SF, Jiao FY, Pettoello-Mantovani M, et al. Behavioral and emotional disorders in children during the COVID-19 epidemic. J Pediatr. (2020) 221:264-6.e1. doi: 10.1016/j.jpeds.2020.03.013

15. Pragholapati A. Covid-19 impact on students. EdArXiv [Preprint]. (2020). doi: 10.35542/osf.io/895ed

16. Wang C, Pan R, Wan X, Tan Y, Xu L, Ho CS, et al. Immediate psychological responses and associated factors during the initial stage of the 2019 coronavirus disease (COVID-19) epidemic among the general population in China. Int J Environ Res Pub Health. (2020) 17:1-25. doi: 10.3390/ijerph17051729

17. Xiao C. A novel approach of consultation on 2019 novel coronavirus (COVID19)-related psychological and mental problems: structured letter therapy. Psychiatry Investig. (2020) 17:175-6. doi: 10.30773/pi.2020.0047

18. Aassve A, Alfani G, Le Moglie M. Epidemics and Trust: The Case of the Spanish $F l u$. Working paper. Innocenzo Gasparini Institute for Economic Research (IGIER), Bocconi University (2020) 661:1-32.

19. Siu JY. Coping with future epidemics: Tai Chi practice as an overcoming strategy used by survivors of severe acute respiratory syndrome (SARS) in post-SARS Hong Kong. Health Expect. (2014) 19:762-72. doi: 10.1111/hex.12270

20. Yang Y, Li W, Zhang Q, Zhang L, Cheung T, Xiang Y-T. Mental health services for older adults in China during the COVID-19 outbreak. Lancet Psychiatry. (2020) 7:22. doi: 10.1016/S2215-0366(20)30079-1

21. Jeong H, Yim HW, Song Y-J, Ki M, Min J-A, Cho J, et al. Mental health status of people isolated due to middle east respiratory syndrome. Epidemiol Health. (2016) 38:e2016048. doi: 10.4178/epih.e2016048

22. Brooks SK, Webster RK, Smith LE, Woodland LJ, Wessely SU, Greenberg N, et al. The psychological impact of quarantine and how to reduce it: rapid review of the evidence. Lancet. (2020) 395:912-20. doi: 10.1016/S0140-6736(20)30460-8

23. Abdel-Rahman AA, Andel-Fattah MM. Prevalence, symptomatology, and the risk factors for depression among high school students in Saudi Arabia. Neurosciences. (2007) 2:8-16. doi: 10.5964/ejop.v2i3.335

24. Adewuya AO, Ola BA, Aloba OO, Mapayi BM, Oginni OO. Depression amongst Nigerian university students: prevalence and sociodemographic correlates. Soc Psychiatry Psychiatry Epidemiol. (2006) 41:674-8. doi: 10.1007/s00127-006-0068-9

25. Al-Gelban KS. Depression, anxiety and stress among Saudi adolescent school boys. J R Soc Promot Health. (2007) 127:33-7. doi: 10.1177/1466424007070492

26. Al-Gelban KS. Prevalence of psychological symptoms in Saudi secondary school girls in Abha, Saudi Arabia. Ann Saudi Med. (2009) 29:275-9. doi: $10.4103 / 0256-4947.55308$ 
27. Amr M, Amin TT, Saddichha S, Al Malki S, Al Samail M, Al Qahtani N, et al. Depression and anxiety among Saudi University students: prevalence and correlates. Arab J Psych. (2013) 24:1-7. doi: 10.12816/0000092

28. Bahhawi TA, Albasheer OB, Makeen AM, Arishi A, Hakami O, Maashi $S$, et al. Depression, anxiety, and stress and their association with khat use: a cross-sectional study among Jazan University students, Saudi Arabia. Neuropsychiatr Dis Treat. (2018) 14:2755-61. doi: 10.2147/NDT.S182744

29. Nerdrum P, Rustøen T, Rønnestad MH. Student psychological distress: a psychometric study of 1750 Norwegian 1st-year undergraduate students. Scand J Educ Res. (2006) 50:95-109. doi: 10.1080/00313830500372075

30. Ovuga E, Boardman J, Wasserman D. Undergraduate student mental health at Makerere University, Uganda. World Psychiatry. (2006) 5:51-2.

31. Steptoa A, Tsuda A, Tanaka Y, Wardle J. Depressive symptoms, socio-economic background, sence of control, and cultural factors in university students from 23 countries. Int J Behav Med. (2007) 14:97-107. doi: 10.1007/BF03004175

32. Stewart-Brown S, Evans J, Patterson J, Petersen S, Doll H, Balding J, et al. The health of students in institutes of higher education: an important and neglected public health problem? J Public Health Med. (2000) 22:492-9. doi: 10.1093/pubmed/22.4.492

33. Al-Gelban KS, Al-Amri HS, Mostafa OA. Prevalence of depression, anxiety and stress as measured by the depression, anxiety, and stress scale (DASS-42) among secondary school girls in Abha, Saudi Arabia. Sultan Qaboos Univ Med J. (2009) 9:140-7.

34. Riyadh Population 2020 (Demographics, Maps, Graphs) (2020). Available online at: https://worldpopulationreview.com/world-cities/riyadhpopulation (accessed October 2, 2020).

35. Zung WWK. A rating instrument for anxiety disorders. Psychosomatics. (1971) 12:371-9. doi: 10.1016/S0033-3182(71)71479-0

36. Dunstan DA, Scott N, Todd AK. Screening for anxiety and depression: reassessing the utility of the Zung scales. BMC Psychiatry. (2017) 17:329. doi: 10.1186/s12888-017-1489-6

37. Zung WWK. How Normal Is Anxiety? Current Concepts. Durham, NC: Upjohn (1980).

38. Dunstan DA, Scott N. Norms for Zung's self-rating anxiety scale. BMC Psychiatry. (2020) 20:1-8. doi: 10.1186/s12888-019-2427-6

39. IBM Corp Released (2013). IBM SPSS Statistics for Windows, Version 22.0. Armonk, NY: IBM Corp.

40. Hosmer D, Lemeshow S. Applied Logistic Regression. New York, NY: Wiley (1989).

41. Tomoda A, Mori K, Kimura M, Takahashi T, Kitamura T. One-year prevalence and incidence of depression among first-year university students in Japan: a preliminary study. Psychiatry Clin Neurosci. (2000) 54:583-91. doi: 10.1046/j.1440-1819.2000.00757.x

42. Voelker R. Mounting student depression taxing campus mental health services. JAMA. (2003) 289:2055-6. doi: 10.1001/jama.289.16.2055

43. Wong JGWS, Cheung EPT, Chan KKC, Ma KKM, Tang SW. Webbased survey of depression, anxiety and stress in first-year tertiary education students in Hong Kong. Aus N Z J Psychiatry. (2006) 40:777-82. doi: 10.1080/j.1440-1614.2006.01883.x

44. Tosevski D, Milovancevic M, Gajic S. Personality and psychopathology of university students. Curr Opin Psychiatry. (2010) 23:48-52. doi: 10.1097/YCO.0b013e328333d625

45. Inam B. Anxiety and depression among students of a medical college in Saudi Arabia. Int J Health Sci. (2007) 1:295-300.

46. Al Salman ZH, Al Debel FA, Al Zakaria FA, Shafey MM, Darwish MA. Anxiety and depression and their relation to the use of electronic devices among secondary school students in Al-Khobar, Saudi Arabia. J Fam Comm Med. (2020) 27:53-61. doi: 10.4103/2230-8229.285820

47. Alyami HS, Naser AY, Dahmash EZ, Alyami MH, Al-Meanazel OT, AlMeanazel AT. Depression and anxiety during 2019 coronavirus disease pandemic in Saudi Arabia: a cross-sectional study. medRxiv [Preprint]. (2020). doi: 10.1101/2020.05.09.20096677

48. Cao W, Fang Z, Hou G, Han M, Xu X, Dong J, et al. The psychological impact of the COVID-19 epidemic on college students in China. Psychiatry Res. (2020) 287:112934. doi: 10.1016/j.psychres.2020.112934

49. Lai J, Ma S, Wang Y, Cai Z, Hu J, Wei N, et al. Factors associated with mental health outcomes among health care workers exposed to coronavirus disease 2019. JAMA Netw Open. (2020) 3:e203976. doi: 10.1001/jamanetworkopen.2020.3976

50. Liu X, Kakade M, Fuller CJ, Fan B, Fang Y, Kong J, et al. Depression after exposure to stressful events: lessons learned from the severe acute respiratory syndrome epidemic. Compr Psychiatry. (2012) 53:15-23. doi: 10.1016/j.comppsych.2011.02.003

51. Taylor MR, Agho KE, Stevens GJ, Raphael B. Factors influencing psychological distress during a disease epidemic: data from Australia’s first outbreak of Equine Influenza. BMC Public Health. (2008) 8:347. doi: 10.1186/1471-2458-8-347

52. Van Bortel T, Basnayake A, Wurie F, Jambai M, Koroma AS, Muana AT, et al. Psychosocial effects of an ebola outbreak at individual, community and international levels. Bull World Health Organ. (2016) 94:210-4. doi: 10.2471/BLT.15.158543

53. Chen Q, Liang M, Li Y, Guo J, Fei D, Wang L, et al. Mental health care for medical staff in China during the COVID-19 outbreak. Lancet Psychiatry. (2020) 7:15-6. doi: 10.1016/S2215-0366(20)30078-X

54. Hawryluck L, Gold WL, Robinson S, Pogorski S, Galea S, Styra R. SARS control and psychological effects of quarantine, Toronto, Canada. Emerg Infect Dis. (2004) 10:1206-12. doi: 10.3201/eid1007.030703

55. Sim K, Chua HC. The psychological impact of SARS: a matter of heart and mind. CMAJ. (2004) 170:811-2. doi: 10.1503/cmaj. 1032003

56. Enarson E, Chakrabarti PGD. Women, Gender, and Disaster: Global and Initiatives (Ed.). New Delhi: Sage Publications (2009).

57. Sehlo MG, Al-Zaben FN, Khlifa DA, Agabawi AK, Akel MS, Nemri IA, et al. Stress among medical students in a college of medicine in Saudi Arabia: sex differences. Middle East Curr Psychiatry. (2018) 25:150-4. doi: 10.1097/01.XME.0000542433.59065.97

58. Almalik M, Alnowaiser A, El Meligy O, Sallam J, Balkheyour Y. Clinical anxiety among Saudi postgraduate pediatric dentistry students in Jeddah city. Inter J Dent. (2018) 2018:5863869. doi: 10.1155/2018/5863869

59. Huang L, Xu F, Liu H. Emotional responses and coping strategies of nurses and nursing college students during COVID-19 outbreak. medRxiv [Preprint]. (2020). doi: 10.1101/2020.03.05.20031898

60. Madhav N, Oppenheim B, Gallivan M, Mulembakani P, Rubin E, Wolfe N. Pandemics: risks, impacts, and mitigation. In: Jamison DT, Gelband H, Horton S, Jha P, Laxminarayan R, Mock CN, Nugent R, editors. Disease Control Priorities, 3rd ed. Washington, DC: D.T. International Bank for Reconstruction and Development/The World Bank (2018). p. 315-45. doi: 10.1596/978-1-4648-0527-1_ch17

61. McKibbin WJ, Fernando R. The Global Macroeconomic Impacts of COVID-19: Seven Scenarios. CAMA Working Paper No. 19/2020 (2020). doi: 10.2139/ssrn.3547729

62. Kekić D, Miladinović S. Functioning of educational systems during an outbreak of acute infectious diseases. In: Kolarić D, Milašinović S, Simeunović-Patić B, editors. Archibald Reiss Days, Proceedings of Thematics Conference of International Significance. Belgrade: Academy of Criminalistic and Police Studies (2013). p. 269-76.

63. Wang $\mathrm{H}$, Xia Q, Xiong Z, Li Z, Xiang W, Yuan Y, et al. The psychological distress and coping styles in the early stages of the 2019 Coronavirus disease (COVID-19) epidemic in the general mainland Chinese population: A web-based survey. PLoS ONE. (2020) 15:e0233410. doi: 10.1371/journal.pone.0233410

64. Ross AGP, Crowe SM, Tyndall MW. Planning for the next global pandemic. Int J Infect Dis. (2015) 38:89-94. doi: 10.1016/j.ijid.2015.07.016

Conflict of Interest: The authors declare that the research was conducted in the absence of any commercial or financial relationships that could be construed as a potential conflict of interest.

Copyright (C) 2020 Khoshaim, Al-Sukayt, Chinna, Nurunnabi, Sundarasen, Kamaludin, Baloch and Hossain. This is an open-access article distributed under the terms of the Creative Commons Attribution License (CC BY). The use, distribution or reproduction in other forums is permitted, provided the original author(s) and the copyright owner(s) are credited and that the original publication in this journal is cited, in accordance with accepted academic practice. No use, distribution or reproduction is permitted which does not comply with these terms. 